\title{
Biological Activity of the tzs Gene of Nopaline Agrobacterium tumefaciens GV3101 in Plant Regeneration and Genetic Transformation
}

\author{
Zhao-Fen Han, ${ }^{1,2}$ David M. Hunter, ${ }^{3}$ Susan Sibbald, ${ }^{2}$ Ji-Shu Zhang, ${ }^{1}$ and Lining Tian ${ }^{2}$ \\ ${ }^{1}$ College of Life Science, Northwest A\&F University, Yangling, Shaanxi Province 712100, P. R. China; ${ }^{2}$ Southern Crop \\ Protection and Food Research Centre, Agriculture and Agri-Food Canada, London, Ontario N5V 4T3, Canada; ${ }^{3}$ Southern \\ Crop Protection and Food Research Centre, Agriculture and Agri-Food Canada, Vineland Station, Ontario LOR 2E0, \\ Canada
}

Submitted 16 June 2013. Accepted 17 April 2013.

\begin{abstract}
Agrobacterium tumefaciens has been widely used in plant genetic transformation. Hormone-encoding genes residing in the T-DNA region have been removed, resulting in disarmed Agrobacterium strains that are used in various transformation experiments. Nopaline Agrobacterium strains, however, carry another hormone gene, trans-zeatin synthesizing $(t z s)$, that codes for trans-zeatin in the virulence region of the tumor-inducing plasmids. We investigated the activity and function of the $t z s$ gene of a nopaline Agrobacterium sp. strain GV3101 in plant in vitro regeneration. Leaf explants of tobacco and Nicotiana benthamiana co-cultured with strain GV3101 exhibited active shoot regeneration in media without added plant growth regulators. On medium without plant growth regulators, transgenic shoots were also induced from explants co-cultured with GV3101 containing a binary vector. Enzyme-linked immunosorbent assay showed that cell-free extracts of Agrobacterium sp. strain GV3101 culture contained the trans-zeatin at 860 ng/liter. Polymerase chain reaction using $t z s$-specific primers showed that the $t z s$ gene was present in strain GV3101 but not in other Agrobacterium strains. The study showed that the $t z s$ gene in GV3101 was actively expressed, and that trans-zeatin produced in the Agrobacterium strain can promote plant shoot regeneration.
\end{abstract}

Agrobacterium tumefaciens is a plant pathogen which can cause gall disease in plant tissues (Braun 1958; De Cleene and De Ley 1976; Zhu et al. 2000). Agrobacterium spp. can transfer the transferred DNA (T-DNA) region of its tumor-inducing (Ti) plasmid into plant cells at the infected wound sites and the T-DNA can then be incorporated into the plant genome. Gall formation is due to the expression of oncogenic genes located in the T-DNA region (Akiyoshi et al. 1987; Citovsky et al. 2007; Gelvin 2003; Jameson 2000; Otten et al. 1999; Shaw 1995). If the oncogenes coding for hormones are removed from the T-DNA region, the result is a disarmed Agrobacterium sp. (Hood et al. 1986; Ooms et al. 1982; Mankin et al. 2007; Palanichelvam et al. 2000; Zhan et al. 1990). When the

Corresponding author: L. Tian; Telephone: 519-457-1470; Fax: 519-4573997; E-mail: lining.tian@agr.gc.ca

(C) 2013 The American Phytopathological Society oncogenes are replaced with genes of interest, these target genes can be transferred into the plant genome. Agrobacterium-mediated plant transformation has now been widely used in molecular biology research and biotechnology for introduction of foreign genes into plant cells. Different Agrobacterium strains that have different features have been developed and used in plant genetic transformation (Hoekema et al. 1984; Holsters et al. 1980; Hood et al. 1993; Hooykaas and Schilperoort 1992; $\mathrm{Hu}$ and Du 2006; Pitzschke and Hirt 2010; Tzfira et al. 2004; Wood et al. 2001).

T-DNA transfer is not regulated by T-DNA itself but is actually mediated by a series of virulence (vir) genes located in the vir region of the Ti plasmid (Cascales and Christie 2004; Christie et al. 2005; Hoekema et al. 1983; Judd et al. 2005; Lacroix and Citovsky 2011; Ziemienowicz et al. 2001). In nopaline-type Agrobacterium strains such as GV3101, the vir region contains a specific gene, trans-zeatin synthesizing ( $t z s)$, that codes for trans-zeatin synthesis (TZS) (Akiyoshi et al. 1985; Beaty et al. 1986; Jameson 2000; Krall et al. 2002). Zeatin is a cytokinin, a main type of phytohormone that can promote cell differentiation and growth (Hwang et al. 2010; Mok and Mok 2001; Sakakibara 2006; Takei et al. 2001). The TZS catalyzes the last step of the biosynthesis of the trans-zeatin ribosides in Agrobacterium (John and Amasino 1988; Krall et al. 2002; Powell and Morris 1986; Powell et al. 1988). Because the tzs gene is not transferred into plant cells and, therefore, does not cause gall disease in plant, this gene has been retained intact in nopaline Agrobacterium strains used in plant transformation.

The biological function of $t z s$ is proposed to stimulate plant cell growth upon infection of Agrobacterium spp. to plant tissues. This stimulation may increase the efficiency of T-DNA transfer into plant cells (Akiyoshi et al. 1987; Beaty et al. 1986; Heinemeyer et al. 1987; Hwang et al. 2010; John and Amasino 1988; Powell et al. 1988). However, thus far, there is no direct evidence for this role during the Agrobacterium-plant interaction. Because tzs does not exist in all Agrobacterium strains, the gene is not considered to be essential for virulence and the tzs-containing Agrobacterium strains do not necessarily generate higher transformation efficiency.

Plant genetic transformation with Agrobacterium spp. is usually conducted with tissue-cultured plant materials, and plant growth regulators (PGR) are normally added into the culture media to promote cell regeneration. We investigated the biological activity of the tzs gene of nopaline Agrobacterium sp. strain GV3101 in plant in vitro culture. 


\section{RESULTS}

Agrobacterium sp. strain GV3101strain promotes plant cell regeneration.

Leaf explants of tobacco and Nicotiana benthamiana were inoculated with Agrobacterium sp. strain GV3101 and then cultured on Murashige and Skoog (MS) medium without adding PGR; specifically, cytokinins. As much as $86 \%$ of tobacco explants showed in vitro shoot regeneration (Table 1) in hormone-free medium. Similarly, $50 \%$ of the $N$. benthamiana explants exhibited vigorous shoot regeneration on medium without PGR (Table 1). No shoot regeneration was observed on explants placed on PGR-free medium and without GV3101 inoculation (Table 1; Fig. 1).

\section{Regeneration with supernatant of GV3101 culture.}

Regeneration of explants inoculated with GV3101 indicated that the bacterium-secreted hormones might have stimulated cell regeneration. Explants inoculated in the supernatant of GV3101 culture for different time lengths and then cultured in PGR-free medium containing timentin to control bacterial growth exhibited shoot regeneration (Fig. 2). It appeared that an 8-h treatment of the explants with supernatant was sufficient to promote shoot regeneration. The regeneration rate increased significantly when the explants were cultured for longer periods of time (Fig. 2).

\section{Evaluation of different Agrobacterium strains on plant regeneration.}

GV3101 belongs to the nopaline Agrobacterium group in which the vir region carries the tzs gene. Regeneration of explants co-cultured with GV3101 indicated that the tzs gene in the strain might be responsible for the regeneration; therefore, strains without the tzs gene should not show a shoot induction effect. To test this, we compared strain GV3101 with three Agrobacterium strains without the tzs gene-namely, LBA4404 (Hoekema et al. 1983), EHA101, and EHA105 (Hood et al. 1993) - on plant regeneration. Tobacco leaf explants were co-cultured with these strains and then placed on PGRfree MS medium. Up to $97.5 \%$ of tobacco explants co-cultured with GV3101 produced shoots (Table 2; Fig. 1B) but no shoot development was observed on explants cultured with the other Agrobacterium strains (Table 2; Fig. 1B). The results also showed that acetosyringone had no effect on shoot production (Table 2; Fig. 1B).

\section{Plant transformation without using PGR.}

Based on the regeneration promotion by GV3101, we then speculated that this Agrobacterium strain might also promote transgenic cell regeneration on medium without PGR. Leaf explants of tobacco and N. benthamiana co-cultured with Agrobacterium sp.strain GV3101 containing the binary vector tCUP$\beta$-glucuronidase (GUS) were placed on a PGR-free medium containing kanamycin, which would inhibit the regeneration of untransformed cells. Although control leaf discs that were not exposed to the Agrobacterium strain did not produce any shoots in the presence of kanamycin, leaf explants inoculated with GV3101/tCUP-GUS exhibited shoot development (Table 3 ). The transformation was confirmed by histochemical analysis of the GUS expression and polymerase chain reaction (PCR) analysis using nptII-specific primers (data not shown) using standard methods well established in our laboratory (Tian et al. 2002, 2003).

\section{Quantification of trans-zeatin}

in the Agrobacterium culture medium.

Different Agrobacterium strains were cultured on Luria-Bertani (LB) medium containing appropriate antibiotics (Table 4). The supernatant of each Agrobacterium strain was purified and trans-zeatin production was quantified using enzyme-linked immunosorbent assay (ELISA). As expected, a significant amount (860 ng/liter) of trans-zeatin was detected in GV3101 culture (Table 5) but no or little trans-zeatin was detected in the media cultured with other Agrobacterium strains.

\section{Analysis of the presence \\ of the $t z s$ gene in Agrobacterium strains.}

DNA primers specific to the tzs gene were designed and used for PCR analysis to detect the presence of the $t z s$ gene in different Agrobacterium strains. A 664-bp DNA fragment cor-

Table 1. Shoot regeneration of tobacco and Nicotiana benthamiana leaf explants incubated with Agrobacterium sp. strain GV3101 on plant growth regulator (PGR)-free medium

\begin{tabular}{|c|c|c|c|c|}
\hline Plant & Culture condition & Number of explants & Response $(\%)$ & Number of shoots/explant $\pm \mathbf{S E}^{\mathrm{y}}$ \\
\hline \multirow{2}{*}{ Tobacco } & No $\mathrm{PGR}^{\mathrm{z}}$ & 50 & 0 & 0 \\
\hline & GV3101 & 48 & 86.00 & $3.65 \pm 0.34$ \\
\hline \multirow[t]{2}{*}{ N. benthamiana } & No $\mathrm{PGR}^{\mathrm{z}}$ & 50 & 0 & 0 \\
\hline & GV3101 & 50 & 50.00 & $1.32 \pm 0.27$ \\
\hline
\end{tabular}

\footnotetext{
${ }^{y} \mathrm{SE}=$ standard error of the mean
}

${ }^{\mathrm{z}}$ No PGR added.

Table 2. Shoot regeneration of tobacco leaf explants co-cultured with different Agrobacterium strains with or without acetosyringone on plant growth regulator-free medium

\begin{tabular}{|c|c|c|c|c|}
\hline Agrobacterium strain & Acetosyringone & Number of explants & Response $(\%)$ & Number of shoots/explant mean $\pm \mathrm{SE}^{\mathrm{z}}$ \\
\hline \multirow[t]{2}{*}{ No } & - & 30 & 0 & 0 \\
\hline & + & 40 & 0 & 0 \\
\hline \multirow[t]{2}{*}{ GV3101 } & - & 39 & 97.50 & $3.59 \pm 0.50 \mathrm{a}$ \\
\hline & + & 40 & 97.51 & $3.83 \pm 0.38 \mathrm{a}$ \\
\hline \multirow[t]{2}{*}{ LBA4404 } & - & 30 & 0 & 0 \\
\hline & + & 40 & 0 & 0 \\
\hline \multirow[t]{2}{*}{ EHA101 } & - & 40 & 0 & 0 \\
\hline & + & 40 & 0 & 0 \\
\hline \multirow[t]{2}{*}{ EHA105 } & - & 40 & 0 & 0 \\
\hline & + & 40 & 0 & 0 \\
\hline
\end{tabular}

$\overline{{ }^{z} \mathrm{SE}}=$ standard error of the mean. Means followed by the same letter are not significantly different $(\mathrm{P}<0.05)$ according to Tukey's honestly significant difference test. 
responding to the $t z s$ gene was amplified from GV3101. No tzs gene was detected in other Agrobacterium strains (Fig. 3).

\section{Plant development and recovery.}

Induced shoots of tobacco and $N$. benthamiana produced following Agrobacterium sp. strain GV3101 inoculation showed normal growth and development. Shoots removed from explants and put into fresh PGR-free medium developed roots. Plantlets further developed in Magenta boxes (Fig. 1Ae and f) prior to transplanting into soil. Normal and full plants were recovered in a greenhouse (Fig. 1Ag and $\mathrm{h}$ ).

\section{DISCUSSION}

The tzs gene in nopaline-type Agrobacterium strains has long been documented (Barry et al. 1984; Beaty et al. 1986). Various studies have been conducted to characterize this gene and reveal the potential biological functions of Agrobacterium spp. in the natural situation (Aly et al. 2008; John and Amasino 1988; Krall et al. 2002; Lee and Gelvin 2008; Powell et al. 1988). Disarmed nopaline Agrobacterium strains have been widely used in plant biotechnology, especially for plant genetic transformation using in vitro culture. In a study on plant transformation, Fillatti and associates (1987) report that using a napoline Agrobacterium sp. strain C58 could enhance the regeneration rate of a poplar hybrid clone in medium where PGR were supplied. They suggested that the $t z$ s gene in the vir region might provide a certain hormone environment that stimulated plant regeneration. However, a systemic study to explore the possible function of the $t z s$ gene with respect to plant regeneration has not previously been reported.

Shoot induction from leaf explants co-cultured with Agrobacterium sp. strain GV3101 was significant. The supernatant of the GV3101 culture also promoted active shoot regeneration. These results indicated that this Agrobacterium strain secreted plant hormones or hormone-like compounds that stimulated

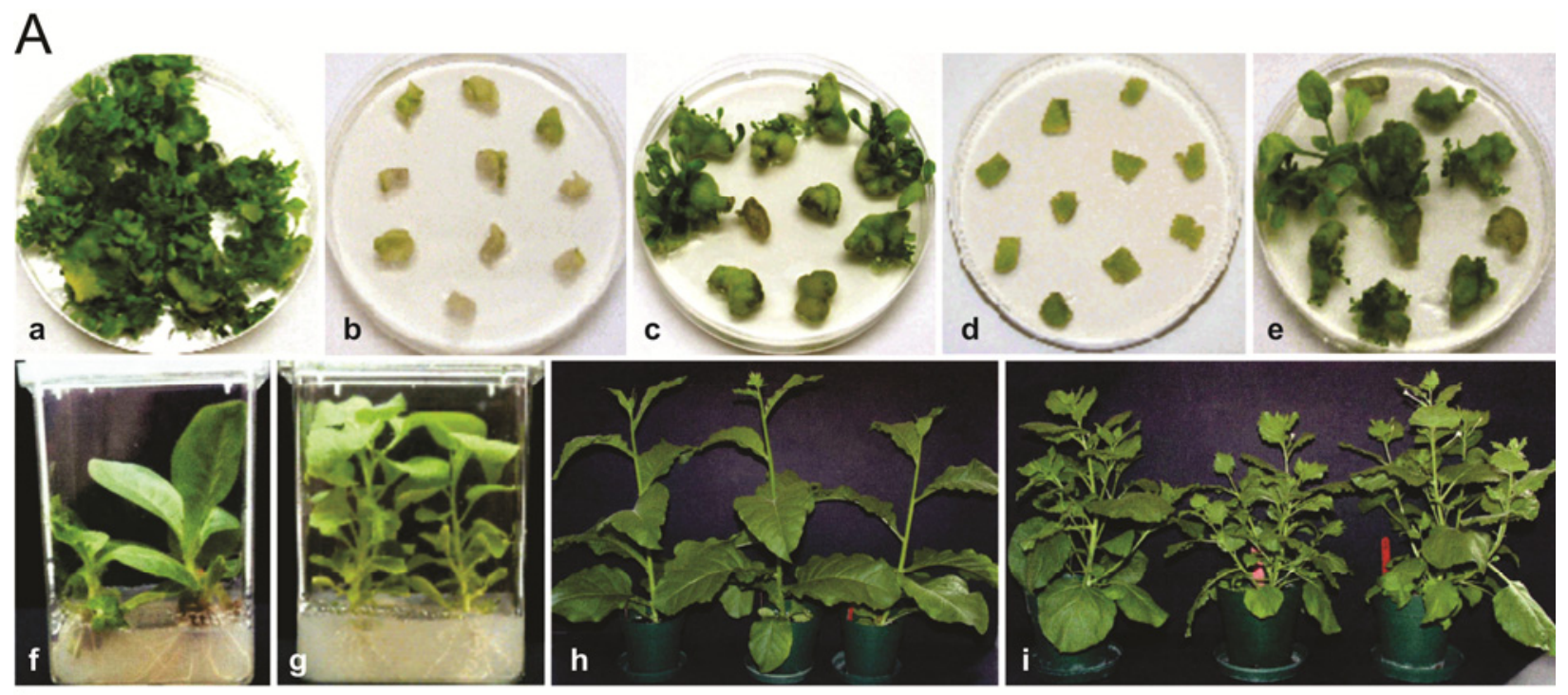

B
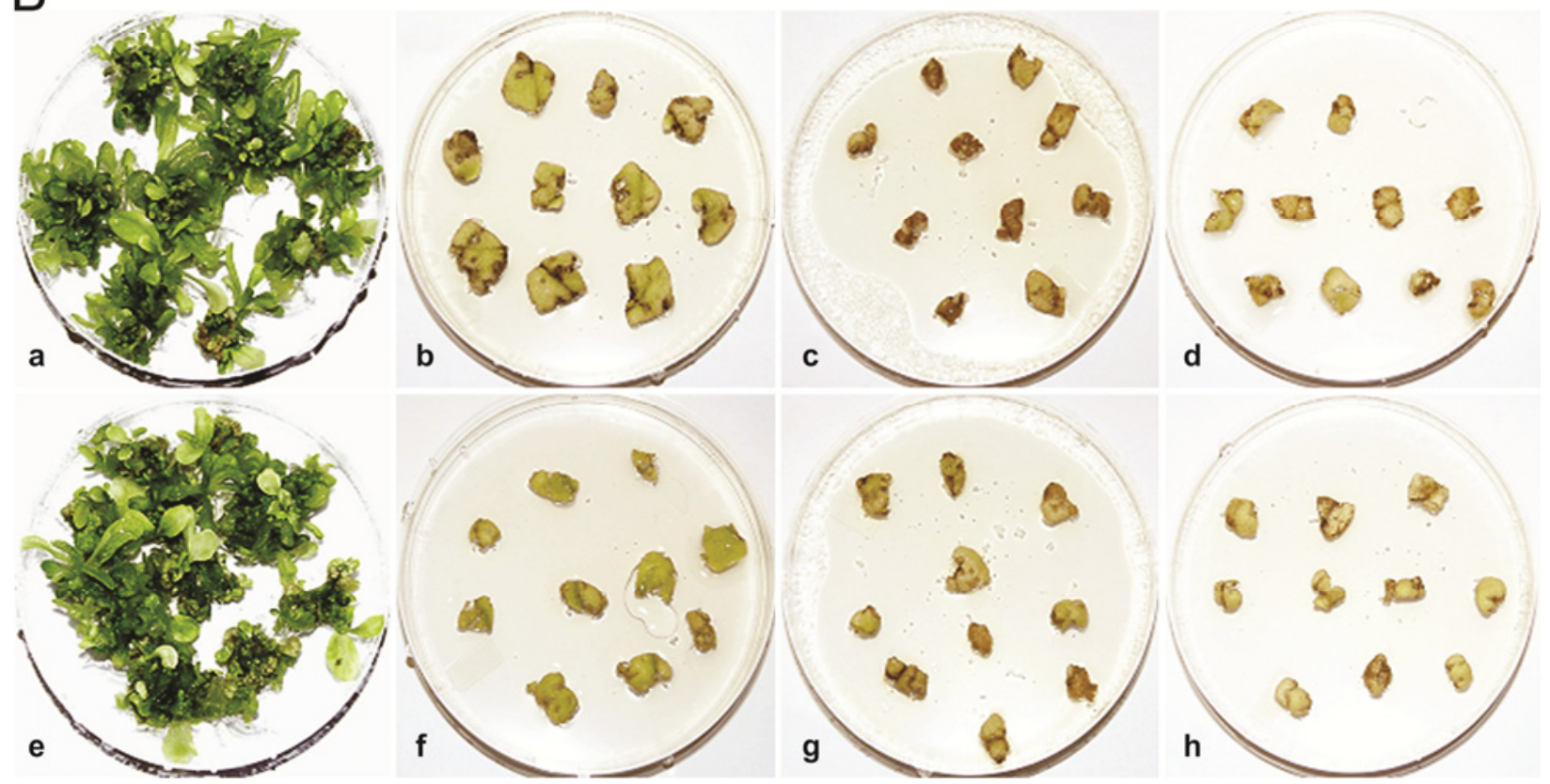

Fig. 1. Plant in vitro regeneration via interactions with different Agrobacterium strains. A, Shoot induction and plant development of tobacco (b, e, and g) and Nicotiana benthamiana (d, f, and h) inoculated with Agrobacterium GV3101. a, Tobacco control and c, N. benthamiana control. B, Shoot induction of tobacco and N. benthamiana inoculated with Agrobacterium strains GV3101 (a and e), LBA4404 (b and f), EHA101 (c and g), and EHA105 (d and h) on plant growth regulator-free medium. 
cell differentiation and regeneration. Strain GV3101 contains a tzs gene (John and Amasino 1988; McKenzie et al. 1994; Powell and Morris 1986) that might be actively producing trans-zeatin, a type of phytohormone. To confirm that in vitro shoot induction was due to the activity of $t z s$ gene in GV3101, three Agrobacterium strains, including LBA4404, EHA101, and EHA105, that do not belong to the nopaline group and do not contain the $t z s$ gene in the Ti plasmid, were evaluated for plant shoot initiation. As expected, shoot regeneration was only observed in explants inoculated with GV3101 and no regeneration was observed with any other strains not belonging to the nopaline group. This further indicated that the observed shoot regen-
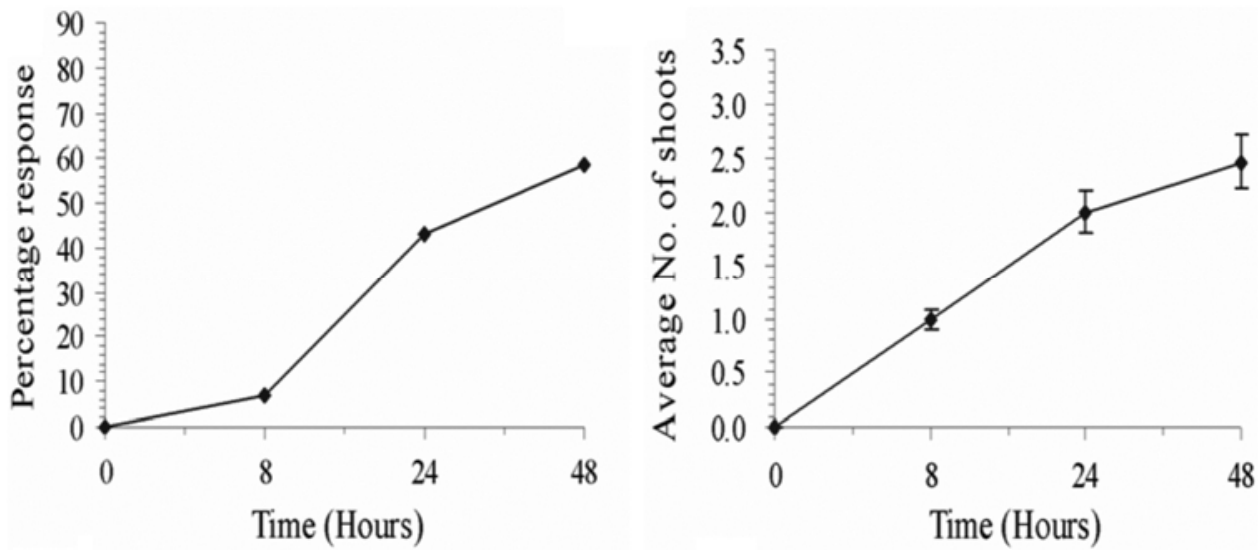

Fig. 2. Shoot induction from tobacco leaf explants inoculated with the supernatant of Agrobacterium GV3101 for different time lengths on plant growth regulator-free medium.

Table 3. Transgenic shoot development of tobacco and Nicotiana benthamiana leaf explants co-cultured with Agrobacterium sp. strain GV3101 on plant growth regulator-free medium

\begin{tabular}{llccc}
\hline Plant & Culture condition & Number of explants & Response (\%) & Number of shoots/explant \pm SE $^{\mathbf{z}}$ \\
\hline Tobacco & Control & 30 & 0 & 0 \\
& GV3101/tCUP & 50 & $20.00 \pm 1.47$ & $0.22 \pm 0.07$ \\
N. benthamiana & Control & 30 & 0 & 0 \\
& GV3101/tCUP & 50 & $16.3 \pm 3.42$ & $0.21 \pm 0.04$ \\
\hline
\end{tabular}

${ }^{\mathrm{z}} \mathrm{SE}=$ standard error of the mean.

Table 4. Disarmed Agrobacterium tumefaciens strains used in the study

\begin{tabular}{|c|c|c|c|c|c|}
\hline Strain name & Chromosomal background & Ti plasmid derivation ${ }^{y}$ & Alkaloids-type & Antibiotic resistance $^{\mathrm{z}}$ & Reference \\
\hline GV3101 & C58 & pTiC58 & Nopaline & Rif, gen & Koncz and Schell 1986 \\
\hline LBA4404 & Ach5 & pTiAch5 & Octopine & Rif & Ooms et al. 1982 \\
\hline EHA101 & C58 & pTiBo542 & Succinamopine & Rif, km & Hood et al. 1986 \\
\hline EHA105 & $\mathrm{C} 58$ & pTiBo542 & Succinamopine & Rif & Hood et al. 1993 \\
\hline
\end{tabular}

${ }^{\mathrm{y}} \mathrm{Ti}=$ tumor inducing.

${ }^{\mathrm{z}}$ Rif $=$ rifampicin, gen = gentamycin, and $\mathrm{km}=$ kanamycin.

Table 5. Levels of trans-zeatin in culture medium inoculated with different Agrobacterium strains

\begin{tabular}{lcccccc}
\hline & \multicolumn{5}{c}{ Agrobacterium strain } \\
\cline { 2 - 6 } Trans-zeatin $(\mathrm{ng} / \mathrm{liter})^{\mathrm{z}}$ & GV3101-blank & GV3101-tCUP & LBA4404 & EHA101 & EHA105 \\
\hline
\end{tabular}

${ }^{\mathrm{z}}$ Data shown \pm standard error of the mean.

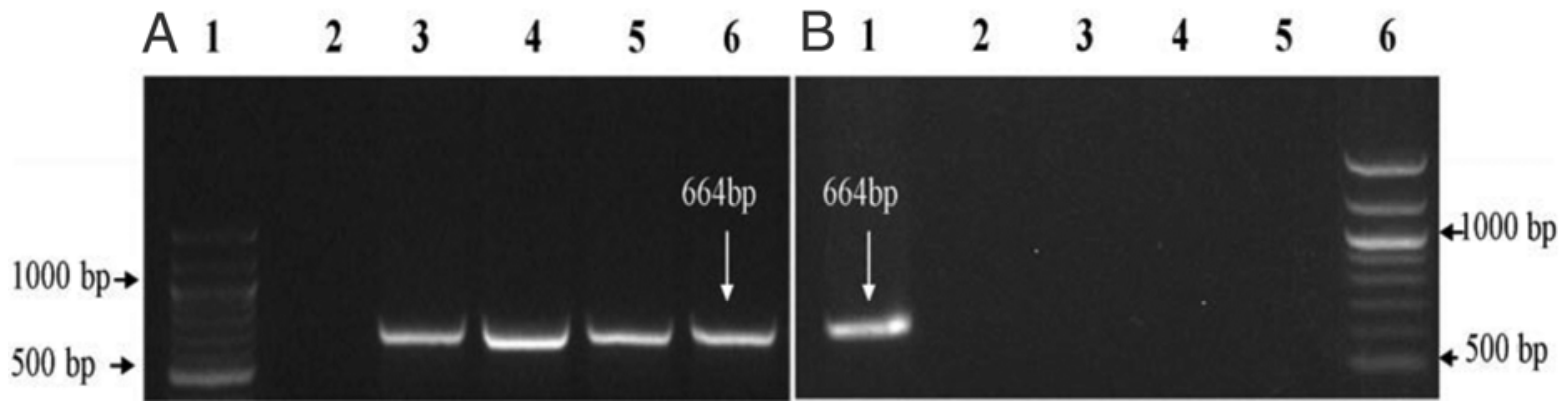

Fig. 3. Polymerase chain reaction analysis of trans-zeatin synthesizing ( $t z s)$ gene in different Agrobacterium strains. A, Lane 1, marker; lane 2, negative control; lane 3, blank GV3101; lanes 4 to 6, GV3101 containing different binary vectors. B, Lane 1, GV3101; lane 2, LBA4404; lane 3, EHA101; lane 4, EHA101; lane 5, negative control; lane 6, marker. 
eration resulted from the activity of the tzs gene in strain GV3101.

Expression of the tzs gene in Agrobacterium strains can be induced by acetosyringone (Anand et al. 2008; Beaty et al. 1986; Cho and Winans 2005; Powell et al. 1988; Sheikholeslam and Weeks 1987; Stachel et al. 1985; Yuan et al. 2007). However, no significant difference in shoot induction was observed in the presence or absence of acetosyringone in this study. Cytokinin production by GV3101 without acetosysingone might be adequate for plant cell regeneration and the incremental effect of acetosyringone was probably minimal in this situation. No shoot induction was observed in explants in the presence of acetosyringone but without GV3101 inoculation. Similar results were also observed using other Agrobacterium strains. Thus, in vitro regeneration of explants co-cultured with GV3101 was not due to acetosyringone.

Except for the flower dip method in Arabidopsis (Bechtold et al. 1993; Hooykaas and Schilperoort 1992; Zhang et al. 2006), plant genetic transformation is usually conducted by inducing in vitro regeneration with PGR being added to the culture media. We speculated that GV3101 could also promote transgenic cell in vitro regeneration. Genetic transformations conducted with GV3101 containing the tCUP-GUS vector (Foster et al. 1999; Tian et al. 2002, 2003) resulted in efficient transgenic shoot development with both tobacco and $N$. benthamiana. Trans-zeatin produced by GV3101 apparently also promoted transgenic cell differentiation for shoot development. Based on this observation, trans-zeatin produced by GV3101 may have partially contributed to the transgenic cell regeneration in various reported transformation experiments in which cytokinin was still added in culture media.

It was proposed that gene $t z s$ might stimulate T-DNA transfer into plant cells (Guo et al. 2005; John and Amasino 1988; Mankin et al. 2007; Vergunst et al. 2005). In a recent study by Hwang and associates (2010), the loss of TZS protein expression by the $t z s$ frameshift $(t z s-f s)$ mutant is associated with reduced tumorgenesis efficiency on white radish stems and reduced transformation efficiencies on Arabidopsis roots. Complementation of the $t z s-f s$ mutant with a wild-type $t z s$ gene restored wild-type levels of trans-zeatin secretions and transformation efficiencies. These data suggest that TZS may contribute to both gene transfer and cell regeneration. Because TZS is not produced by all Agrobacterium strains, the tzs gene is not considered to be essential for T-DNA transfer. The $t z s$ gene may be a host range factor contributing to Agrobacterium infection in certain plants (Aly et al. 2008; Hwang et al. 2010; Hooykaas and Schilperoort 1992; Zupan et al. 2000). Further research is needed to investigate the involvement of the $t z S$ gene in plant genetic transformation.

A molecular biology approach was applied to analyze the $t z s$ gene in Agrobacterium strains. The presence of the tzs gene in GV3101 was confirmed by PCR using $t z s$-specific primers. The tzs gene was not detected in other Agrobacterium strains that do not belong to nopaline group. These results are in agreement with earlier studies that showed that the $t z s$ gene was present only in nopaline Agrobacterium strains (Akiyoshi et al. 1985; Beaty et al. 1986; Regier and Morris 1982; Veselov et al. 2003). A significant production of trans-zeatin by GV3101 was determined by ELISA, indicating that zeatin produced in GV3101 culture contributed to shoot in vitro regeneration observed in the study. In a recent study, transgenic poplars containing the $t z s$ gene controlled by the $35 \mathrm{~S}$ promoter showed high levels of cellular zeatin, and various plant development phenotypes associated with cytokinin-mediated morphogenesis were observed (Choi et al. 2009). When the isopentenyl transferase (ipt) gene from Agrobacterium was introduced into kiwifruit, the content of a trans-zeatin precursor increased in the transgenic line, indi- cating that morphological changes were related to expression of the ipt gene (Honda et al. 2011). Similarly, trans-zeatin produced by the expression of the $t z s$ gene had the biological function and, indeed, stimulated cell division and growth.

This study, for the first time, reports that the $t z s$ gene in a nopaline Agrobacterium strain actively expressed and produced a significant amount of trans-zeatin. The hormone produced showed biological function, induced plant cell differentiation, and promoted in vitro shoot development normally.

\section{MATERIALS AND METHODS}

\section{Plant materials.}

The donor plants of tobacco ( $N$. tobacum) 'SR1' and N. benthamiana were maintained in vitro on MS medium (Murashige and Skoog 1962) in Magenta containers. The plants were propagated by subculturing the plant notes onto fresh medium every 2 months and were maintained at $25^{\circ} \mathrm{C}$ in white light at approximately 54 to $72 \mu \mathrm{mol} \mathrm{m} \mathrm{m}^{-2} \mathrm{~s}^{-1}$ with light and dark photoperiods of 16 and $8 \mathrm{~h}$, respectively.

\section{Agrobacterium strain preparation.}

Four A. tumefaciens strains were used in this research (Table 4). Strain GV3101/PMP90 was obtained from B. Miki's laboratory collection, Agriculture and Agri-Food Canada, Ottawa. LBA4404 was purchased from Invitrogen Inc. EHA101 and EHA105 were kindly provided by R. Scorza (United States Department of Agriculture Appalachian Fruit Research Station Kearneysville, WV, U.S.A.). Agrobacterium strains were grown in liquid LB medium (Miller 1972) containing appropriate antibiotics (Table 4) at $28^{\circ} \mathrm{C}$ to mid-log phase (with an optical density at $600 \mathrm{~nm}\left[\mathrm{OD}_{600}\right]$ of approximately 1$)$. The culture was diluted 1:1 with LB medium for plant inoculation.

The tCUP-GUS (Foster et al. 1999) was cloned into pRD400 as described before (Tian et al. 2003). The construct was introduced into A. tumefaciens GV3101/pMP90 by electroporation and cultured in LB medium with appropriate antibiotics.

\section{Plant explant inoculation.}

Plant leaves were cut into $0.5-\mathrm{cm}^{2}$ pieces in a laminar hood. The explants were dipped in Agrobacterium culture solution for $15 \mathrm{~min}$ and then placed on sterile filter paper to remove excess Agrobacterium solution. Explants were cultured on MS salts (Murashige and Skoog 1962), B5 vitamins (Gamborg et al. 1968), 3\% sucrose, and 0.25\% Gelrite, pH 5.7, as described by Tian and associates (2002) but without PGR. After co-culturing for 2 days, explants were placed on PGR-free MS medium with timentin (300 mg/liter) to inhibit Agrobacterium growth and the culture was maintained under the conditions described previously.

\section{Co-culture with supernatant of GV3101.}

The Agrobacterium sp. strain GV3101 culture was cultured until the $\mathrm{OD}_{600}$ reached approximately 1 . The culture was centrifuged for $15 \mathrm{~min}$ at 5,000 rpm and the supernatant was collected. Explants were dipped in the supernatant for $15 \mathrm{~min}$ and then placed on PGR-free MS medium. After 8, 24, and $48 \mathrm{~h}$, explants were transferred to PGR-free MS medium containing timentin.

\section{Plant genetic transformation.}

Tobacco and N. benthamiana leaf explants were co-cultured with GV3101 containing tCUP-GUS binary vector (Foster et al. 1999; Tian et al. 2003). Explants were then maintained on MS medium containing timentin (300 mg/liter) and kanamycin (100 mg/liter). The transformation followed the procedure described previously (Tian et al. 2002, 2003). 


\section{PCR analysis of the $t z s$ gene \\ in different Agrobacterium strains.}

To analyze the presence of the tzs gene in different Agrobacterium strains, a PCR was performed using $t z s$-specific primers. The primers used (forward primer: $5^{\prime}$-TCTGGCCACTGAGG AAAATC- $3^{\prime}$ and reverse primer: $5^{\prime}$-ATCTACGGACCGACTT GCAG-3') were designed online by software primer 5 and the specificity of the primer was verified online by BLAST of National Center for Biotechnology Information. The expected length of the PCR product was $664 \mathrm{bp}$.

Agrobacterium cultures were grown and prepared as described earlier. A single bacterial colony was added to the PCR reaction solution as the template for each PCR analysis. The PCR reaction contained $2 \mu \mathrm{l}$ of $10 \times$ buffer, $1 \mu \mathrm{l}$ of primer mix, $0.4 \mu \mathrm{l}$ of dNTP $(10 \times), 16.4 \mu \mathrm{l}$ of water, and $0.2 \mu \mathrm{l}$ of Taq DNA polymerase (Qiagen, Basel, Switzerland U.S.A.). DNA amplification reactions were performed in a thermocycler (model mastercycler gradient; Eppendorf Canada Ltd., Mississauga, Ontario, Canada) with the following conditions: 1 cycle at $94^{\circ} \mathrm{C}$ for $5 \mathrm{~min} ; 35$ cycles at $94^{\circ} \mathrm{C}$ for $30 \mathrm{~s}, 58^{\circ} \mathrm{C}$ for $1 \mathrm{~min}$, and $72^{\circ} \mathrm{C}$ for $1 \mathrm{~min}$; and a final step of $72^{\circ} \mathrm{C}$ for $4 \mathrm{~min}$. Amplification products were separated by $1.2 \%$ agarose gel electrophoresis, stained with ethidium bromide, and photographed.

\section{Quantification of trans-zeatin \\ in the bacterium culture medium.}

The quantification of trans-zeatin was conducted by ELISA. All strains of Agrobacterium were grown in $500 \mathrm{ml}$ of LB medium containing appropriate antibiotics to mid-log phase (with $\mathrm{OD}_{600}$ at approximately 1). Samples were extracted with $80 \%$ methanol for $12 \mathrm{~h}$ at $4^{\circ} \mathrm{C}$ in the dark. The homogenate was filtered and methanol fractions of the extracts were passed through $\mathrm{a} \mathrm{C}_{18}$ Sep-Pak cartridge (Waters, Milford, MA, U.S.A.). Eluates were evaporated in vacuum at $40^{\circ} \mathrm{C}$ to leave an aqueous phase which was then diluted with 9 volumes of $40 \mathrm{mM}$ ammonium acetate ( $\mathrm{pH}$ 6.5). Diethylaminoethyl (DEAE) equilibrium cellulose $(4 \mathrm{mg})$ in $40 \mathrm{mM}$ ammonium acetate ( $\mathrm{pH} \mathrm{6.5)}$ was added and the mixture was shaken for 10 min (Banowetz 1992). After centrifugation to remove the DEAE cellulose, the supernatant was passed through a $\mathrm{C}_{18}$ Sep-Pak cartridge, which was then washed with $0.1 \mathrm{M}$ acetic acid and eluted with $6 \mathrm{ml} \mathrm{25 \%}$ methanol in $0.1 \mathrm{M}$ acetic acid (vol/vol). After being concentrated with PEG2000 to a volume of $0.5 \mathrm{ml}$, trans-zeatin was quantified by ELISA. The amount of trans-zeatin was calculated by a commercial immunoassay kit for trans-zeatin ribosides (Phytodetek; AgDia Inc., Elkhart, IN, U.S.A.). ELISAs were performed according to the manufacturer's protocol.

\section{Statistical analysis.}

Data were analyzed using SPSS 16.0 .2 computer statistical program (IBM SPSS, Armonk, NY, U.S.A.) and treatment means were compared using Tukey's honestly significant difference test at the probability of $5 \%$.

\section{ACKNOWLEDGMENTS}

We thank K. Leach, G. Seaward, and E. Annen for technical assistance with the research for the in vitro experiments; Z. Xinmei for ELISA analysis; B. Miki and R. Scorza for providing Agrobacterium strains; and D. Drew, the librarian of Agriculture and Agri-Food Canada, for reference checking and alignment. The research was partially supported through a scholarship to Z.-F. Han by the China Scholarship Council.

\section{LITERATURE CITED}

Akiyoshi, D. E., Regier, D. A., Jen, G., and Gordon, M. P. 1985. Cloning and nucleotide sequence of the $t z s$ gene from Agrobacterium tumefaciens strain T37. Nucleic Acids Res. 13:2773-2788.
Akiyoshi, D. E., Regier, D. A., and Gordon, M. P. 1987. Cytokinin production by Agrobacterium and Pseudomonas spp. J. Bacteriol. 169:42424248 .

Aly, K. A., Krall, L., Lottspeich, F., and Baron, C. 2008. The type IV secretion system component VirV5 binds to the trans-zeatin biosynthetic enzyme Tzs and enables its translocation to the cell surface of Agrobacterium tumefaciens. J. Bacteriol. 190:1595-1604.

Anand, A., Uppalapati, S. R., Ryu, C. M., Allen, S. N., Kang, L., Tang, Y., and Mysore, K. S. 2008. Salicylic acid and systemic acquired resistance play a role in attenuating crown gall disease caused by Agrobacterium tumefaciens. Plant Physiol. 146:703-715.

Banowetz, G. M. 1992. The effects of endogenous cytokinin content on benzyladenine-enhanced nitrate reductase induction. Physiol. Plant. 86:341-348.

Barry, G. F., Rogers, S. G., Fraley, R. T., and Brand, L. 1984. Identification of a cloned cytokinin biosynthetic gene. Proc. Natl. Acad. Sci. U.S.A. 81:4776-4780.

Beaty, J. S., Powell, G. K., Lica, L., Regier, D. A., MacDonald, E. M. S., Hommes, N. G., and Morris, R. O. 1986. Tzs, a nopaline Ti plasmid gene from Agrobacterium tumefaciens associated with trans-zeatin biosynthesis. Mol. Gen. Genet. 203:274-280.

Bechtold, N., Ellis, J., and Pelletier, G. 1993. In planta Agrobacterium mediated gene transfer by infiltration of adult Arabidopsis thaliana plants. C. R. Acad. Sci. Ser. III 316:1194-1199.

Braun, A. C. 1958. A physiological basis for autonomous growth of the crown-gall tumor cell proc. Natl. Acad. Sci. U.S.A. 44:344-349.

Cascales, E., and Christie, P. J. 2004. Definition of a bacterial type IV secretion pathway for a DNA substrate. Science 304:1170-1173.

Cho, H., and Winans, S. C. 2005. VirA and VirG activate the Ti plasmid repABC operon, elevating plasmid copy number in response to woundreleased chemical signals. Proc. Natl. Acad. Sci. U.S.A. 102:14843 14848.

Choi, Y., Noh, E., and Choi, K. 2009. Low level expression of prokaryotic tzs gene enhances growth performance of transgenic poplars. Trees 23:741-750.

Christie, P. J., Atmakuri, K., Krishnamoorthy, V., Jakubowski, S., and Cascales, E. 2005. Biogenesis, architecture, and function of bacterial type IV secretion systems. Annu. Rev. Microbiol. 59:451-485.

Citovsky, V., Kozlovsky, S. V., Lacroix, B., Zaltsman, A., Dafny-Yelin, M., Vyas, S., Tovkach, A., and Tzfira, T. 2007. Biological systems of the host cell involved in Agrobacterium infection. Cell. Microbiol. 9:9-20.

De Cleene, M., and De Ley, J. 1976. The host range of crown gall. Bot. Rev. 42:389-466.

Fillatti, J. J., Sellmer, J., McCown, B., Haissig, B., and Comai, L. 1987. Agrobacterium mediated transformation and regeneration of Populus. Mol. Gen Genet. 206:192-199.

Foster, E., Hattori, J., Labbé, H., Ouellet, T., Fobert, P. R., James, L. E., Iyer, V. N., and Miki, B. L. 1999. A tobacco cryptic constitutive promoter, $t C U P$, revealed by T-DNA tagging. Plant Mol. Biol. 41:45-55.

Gamborg, O. L., Miller, R. A., and Ojima, K. 1968. Nutrient requirements of suspension cultures of soybean root cells. Exp. Cell Res. 50:151-158.

Gelvin, S. B. 2003. Agrobacterium-mediated plant transformation: The biology behind the "gene-jockeying" tool. Microbiol. Mol. Biol. Rev. 67:16-37.

Guo, J., Hu, X., and Duan, R. 2005. Interactive effects of cytokinins, light, and sucrose on the phenotypes and the syntheses of anthocyanins and lignins in cytokinin overproducing transgenic Arabidopsis. J. Plant Growth Regul. 24:93-101.

Heinemeyer, W., Buchmann, I., Tonge, D. W., Windass, J. D., Alt-Moerbe, J., Weiler, E. W., Botz, T., and Schröder, J. 1987. Two Agrobacterium tumefaciens genes for cytokinin biosynthesis: Ti plasmid-coded isopentenyltransferases adapted for function in prokaryotic or eukaryotic cells. Mol. Gen. Genet. 210:156-164.

Hoekema, A., Hirsch, P. R., Hooykaas, P. J. J., and Schilperoort, R. A. 1983. A binary plant vector strategy based on separation of vir- and T-region of the Agrobacterium tumefaciens Ti-plasmid. Nature 303:179180.

Hoekema, A., Roelvink, P. W., Hooykaas, P. J. J., and Schilperoort, R. A. 1984. Delivery of T-DNA from the Agrobacterium tumefaciens chromosome into plant cells. EMBO (Eur. Mol. Biol. Organ.) J. 3:2485-2490.

Holsters, M., Silva, B., Van Vliet, F., Genetello, C., De Block, M., Dhaese, P., Depicker, A., Inzé, D., Engler, G., Villarroel, R., Van Montagu, M., and Schell, J. 1980. The functional organization of the nopaline $A$. tumefaciens plasmid pTiC58. Plasmid 3:212-230.

Honda, C., Kusaba, S., Nishijima, T., and Moriguchi, T. 2011. Transformation of kiwifruit using the ipt gene alters tree architecture. Plant Cell Tiss. Org. Cult. 107:45-53.

Hood, E. E., Helmer, G. L., Fraley, R. T., and Chilton, M. D. 1986. The hypervirulence of Agrobacterium tumefaciens A281 is encoded in a region of pTiBo542 outside of T-DNA. J. Bacteriol. 168:1291-1301. 
Hood, E. E., Gelvin, S. B., Melchers, L. S., and Hoekema, A. 1993. New Agrobacterium helper plasmids for gene transfer to plants. Transgenic Res. 2:208-218.

Hooykaas, P. J. J., and Schilperoort, R. A. 1992. Agrobacterium and plant genetic engineering. Plant Mol. Biol. 20:175.

$\mathrm{Hu}, \mathrm{Z}$. B., and Du, M. 2006. Hairy root and its application in plant genetic engineering. J. Integr. Plant Biol. 48:121-127.

Hwang, H. H., Wang, M. H., Lee, Y. L., Tsai, Y. L., Li, Y. H., Yang, F. J., Liao, Y. C., Lin, S. K., and Lai, E. M. 2010. Agrobacterium-produced and exogenous cytokinin-modulated Agrobacterium-mediated plant transformation. Mol. Plant Pathol. 11:677-690.

Jameson, P. E. 2000. Cytokinins and auxins in plant-pathogen interactions-An overview. Plant Growth Regul. 32:369-380.

John, M. C., and Amasino, R. M. 1988. Expression of an Agrobacterium Ti plasmid gene involved in cytokinin biosynthesis is regulated by virulence loci and induced by plant phenolic compounds. J. Bacteriol. 170:790-795

Judd, P. K., Kumar, R. B., and Das, A. 2005. Spatial location and requirements for the assembly of the Agrobacterium tumefaciens type IV secretion apparatus. Proc. Natl. Acad. Sci. U.S.A. 102:11498-11503.

Koncz, C., and Schell, J. 1986. The promoter of TL-DNA gene 5 controls the tissue-specific expression of chimaeric genes carried by a novel type of Agrobacterium binary vector. Mol. Gen. Genet. 204:383-396.

Krall, L., Raschke, M., Zenk, M. H., and Baron, C. 2002. The Tzs protein from Agrobacterium tumefaciens C58 produces zeatin riboside 5'-phosphate from 4-hydroxy-3-methyl-2-(E)-butenyl diphosphate and AMP. FEBS (Fed. Eur. Biochem. Soc.) Lett. 527:315-318.

Lacroix, B., and Citovsky, V. 2011. Extracellular VirB5 enhances T-DNA transfer from Agrobacterium to the host plant. PLoS One 6:e25578. Published online.

Lee, L. Y., and Gelvin, S. B. 2008. T-DNA binary vectors and systems. Plant Physiol. 146:325-332.

Mankin, S. L., Hill, D. S., Olhoft, P. M., Toren, E., Wenck, A. R., Nea, L., Xing, L., Brown, J. A., Fu, H., Ireland, L., Jia, H., Hillebrand, H., Jones, T., and Song, H. S. 2007. Disarming and sequencing of Agrobacterium rhizogenes strain K599 (NCPPB2659) plasmid pRi2659. In Vitro Cell. Dev. Biol. Plant 43:521-535.

McKenzie, M. J., Jameson, P. E., and Poulter, R. T. M. 1994. Cloning an ipt gene from Agrobacterium tumefaciens: Characterisation of cytokinins in derivative transgenic plant tissue. Plant Growth Regul. 14:217228

Miller, J. H. 1972. Experiments in Molecular Genetics. Cold Spring Harbour Laboratory Press, Cold Spring Harbour, NY, U.S.A.

Mok, D. W. S., and Mok, M. C. 2001. Cytokinin metabolism and action. Annu. Rev. Plant Biol. 52:89-118.

Murashige, T., and Skoog, F. 1962. A revised medium for rapid growth and bioassay with tobacco tissue cultures. Physiol. Plant. 15:473-497.

Ooms, G., Hooykaas, P. J. J., Van Veen, R. J. M., Van Beelen, P., Regensburg-Tuïnk, T. J. G., and Schilperoort, R. A. 1982. Octopine tiplasmid deletion mutants of Agrobacterium tumefaciens with emphasis on the right side of the T-region. Plasmid 7:15-29.

Otten, L., Salomone, J. Y., Helfer, A., Schmidt, J., Hammann, P., and De Ruffray, P. 1999. Sequence and functional analysis of the left-hand part of the T-region from the nopaline-type Ti plasmid, pTiC58. Plant Mol. Biol. 41:765-776.

Palanichelvam, K., Oger, P., Clough, S. J., Cha, C., Bent, A. F., and Farrand, S. K. 2000. A second T-region of the soybean-supervirulent chrysopinetype Ti plasmid pTiChry5, and construction of a fully disarmed vir helper plasmid. Mol. Plant-Microbe Interact. 13:1081-1091.

Pitzschke, A., and Hirt, H. 2010. New insights into an old story: Agrobacterium-induced tumour formation in plants by plant transformation. EMBO (Eur. Mol. Biol. Organ.) J. 29:1021-1032.

Powell, G. K., and Morris, R. O. 1986. Nucleotide sequence and expression of a Pseudomonas savastanoi cytokinin biosynthetic gene: Homology with Agrobacterium tumefaciens tmr and tzs loci. Nucleic Acids Res. 14:2555-2565.

Powell, G. K., Hommes, N. G., Kuo, J., Castle, L. A., and Morris, R. O. 1988. Inducible expression of cytokinin biosynthesis in Agrobacterium tumefaciens by plant phenolics. Mol. Plant-Microbe Interact. 1:235242 .
Regier, D. A., and Morris, R. O. 1982. Secretion of trans-zeatin by Agrobacterium tumefaciens: A function determined by the nopaline Ti plasmid. Biochem. Biophys. Res. Commun. 104:1560-1566.

Sakakibara, H. 2006. Cytokinins: Activity, biosynthesis, and translocation Annu. Rev. Plant Biol. 57:431-449.

Shaw, C. H. 1995. Introduction of cloning plasmids into Agrobacterium tumefaciens. Methods Mol. Biol. 49:33-37.

Sheikholeslam, S. N., and Weeks, D. P. 1987. Acetosyringone promotes high efficiency transformation of Arabidopsis thaliana explants by Agrobacterium tumefaciens. Plant Mol. Biol. 8:291-298.

Stachel, S. E., Messens, E., Montagu, M. V., and Zambryski, P. 1985. Identification of the signal molecules produced by wounded plant cells that activate T-DNA transfer in Agrobacterium tumefaciens. Nature 318:624-629

Takei, K., Sakakibara, H., and Sugiyama, T. 2001. Identification of genes encoding adenylate isopentenyltransferase, a cytokinin biosynthesis enzyme, in Arabidopsis thaliana. J. Biol. Chem. 276:26405-26410.

Tian, L. N., Wang, H., Wu, K., Latoszek-Green, M., Hu, M., Miki, B., and Brown, D. C. W. 2002. Efficient recovery of transgenic plants through organogenesis and embryogenesis using a cryptic promoter to drive marker gene expression. Plant Cell Rep. 20:1181-1187.

Tian, L. N., Wu, K. Q., Levasseur, C., Ouellet, T., Foster, E., LatoszekGreen, M., Sibbald, S., Miki, B., Seguin, A., and Brown, D. C. W. 2003. Activity of elements from the tobacco cryptic promoter, $t C U P$, in conifer tissues. In Vitro Cell. Dev. Biol. Plant 39:193-202.

Tzfira, T., Vaidya, M., and Citovsky, V. 2004. Involvement of targeted proteolysis in plant genetic transformation by Agrobacterium. Nature 430:87-92.

Vergunst, A. C., Van Lier, M. C. M., Den Dulk-Ras, A., Grosse Stüve, T. A., Ouwehand, A., and Hooykaas, P. J. J. 2005. Positive charge is an important feature of the C-terminal transport signal of the VirB/D4translocated proteins of Agrobacterium. Proc. Natl. Acad. Sci. U.S.A. 102:832-837.

Veselov, D., Langhans, M., Hartung, W., Aloni, R., Feussner, I., Götz, C., Veselova, S., Schlomski, S., Dickler, C., Bächmann, K., and Ullrich, C. I. 2003. Development of Agrobacterium tumefaciens C58-induced plant tumors and impact on host shoots are controlled by a cascade of jasmonic acid, auxin, cytokinin, ethylene and abscisic acid. Planta 216:512-522

Wood, D. W., Setubal, J. C., Kaul, R., Monks, D. E., Kitajima, J. P., Okura, V. K., Zhou, Y., Chen, L., Wood, G. E., Almeida, N. F., Jr., Woo, L., Chen, Y., Paulsen, I. T., Eisen, J. A., Karp, P. D., Bovee, D., Sr., Chapman, P., Clendenning, J., Deatherage, G., Gillet, W., Grant, C., Kutyavin, T., Levy, R., Li, M. J., McClelland, E., Palmieri, A., Raymond, C., Rouse, G., Saenphimmachak, C., Wu, Z., Romero, P., Gordon, D., Zhang, S., Yoo, H., Tao, Y., Biddle, P., Jung, M., Krespan, W., Perry, M., Gordon-Kamm, B., Liao, L., Kim, S., Hendrick, C., Zhao, Z. Y., Dolan, M., Chumley, F., Tingey, S. V., Tomb, J. F., Gordon, M. P., Olson, M. V., and Nester, E. W. 2001. The genome of the natural genetic engineer Agrobacterium tumefaciens C58. Science 294:2317-2323.

Yuan, Z. C., Edlind, M. P., Liu, P., Saenkham, P., Banta, L. M., Wise, A. A., Ronzone, E., Binns, A. N., Kerr, K., and Nester, E. W. 2007. The plant signal salicylic acid shuts down expression of the vir regulon and activates quormone-quenching genes in Agrobacterium. Proc. Natl. Acad. Sci. U.S.A. 104:11790-11795.

Zhan, X. C., Jones, D. A., and Kerr, A. 1990. The pTiC 58 tzs gene promotes high-efficiency root induction by agropine strain 1855 of Agrobacterium rhizogenes. Plant Mol. Biol. 14:785-792.

Zhang, X., Henriques, R., Lin, S. S., Niu, Q. W., and Chua, N. H. 2006. Agrobacterium-mediated transformation of Arabidopsis thaliana using the floral dip method. Nat. Prot. 1:641-646.

Zhu, J., Oger, P. M., Schrammeijer, B., Hooykaas, P. J. J., Farrand, S. K. and Winans, S. C. 2000. The bases of crown gall tumorigenesis. J. Bacteriol. 182:3885-3895.

Ziemienowicz, A., Merkle, T., Schoumacher, F., Hohn, B., and Rossi, L. 2001. Import of Agrobacterium T-DNA into plant nuclei: Two distinct functions of VirD2 and VirE2 proteins. Plant Cell 13:369-383.

Zupan, J., Muth, T. R., Draper, O., and Zambryski, P. 2000. The transfer of DNA from Agrobacterium tumefaciens into plants: A feast of fundamental insights. Plant J. 23:11-28. 